\title{
Some remarks on the evolution of sedimentary basins along the eastern Brazilian continental margin
}

\author{
1 Petrobras Internacional S.A. - Braspetro, Rua General Canabarro, 500-10 ${ }^{\text {th }}$ floor, 20.271-900 Rio de Janeiro, RJ, Brazil, \\ E-mail: cainelli@braspetro.petrobras.com.br \\ 2 Petróleo Brasileiro S.A. - Exploration \& Production, Avda. Chile, 65-13 ${ }^{\text {th }}$ floor, 20.035-900 Rio de Janeiro, RJ, Brazil, \\ E-mail: webmohr@ep.petrobras.com.br
}

This work provides a general overview of the tectono-stratigraphic evolution of the Eastern Brazilian Margin, discussing the main phases of subsidence and sedimentation and in particular, the structural styles and depositional megasequences of selected basins. The Mesozoic sedimentation along the Brazilian continental margin started with the breakup of Western Gondwana in the Late Jurassic/Early Cretaceous. The rifting of the southernmost part of South America Plate was heralded by the extrusion of flood basalts in the Paraná, Campos and Santos basins. The syn-rift phase is associated with synthetic and antithetic faults forming several half-grabens filled with fluvial-deltaic sediments of the Continental Megasequence. The Transitional Megasequence is characterized by evaporite deposition from the Santos towards the Sergipe/Alagoas Basin, and salt movements constitute one of the most important controls on stratigraphic and structural features, being responsible for several exploratory plays in deep water regions. The drift Marine Megasequence, presently bearing most of the hydrocarbon production and reserves, may be subdivided into a carbonate Restricted Marine Supersequence (Albian to Turonian) and a siliciclastic Open Marine Supersequence (Late Cretaceous to Quaternary). The interpretation of deep water depositional systems and the rift architecture at the transition from continental to oceanic crust constitute the major challenges for petroleum exploration in the next century.

\section{Introduction}

Brazil has one of the world's largest series of basins along a divergent continental margin, and petroleum exploration activities in the past decades resulted in a very large data set along diverse segments of the whole margin (e.g., Asmus and Pontes, 1973; Ponte et al., 1980; Ojeda, 1982; Guardado et al., 1989; Mohriak et al., 1990a; 1990c ; Chang et al., 1992; Matos, 1992; Demercian et al., 1993). The main objective of this work, which is based on a short course presented at the Rio '98 AAPG International Conference (Cainelli

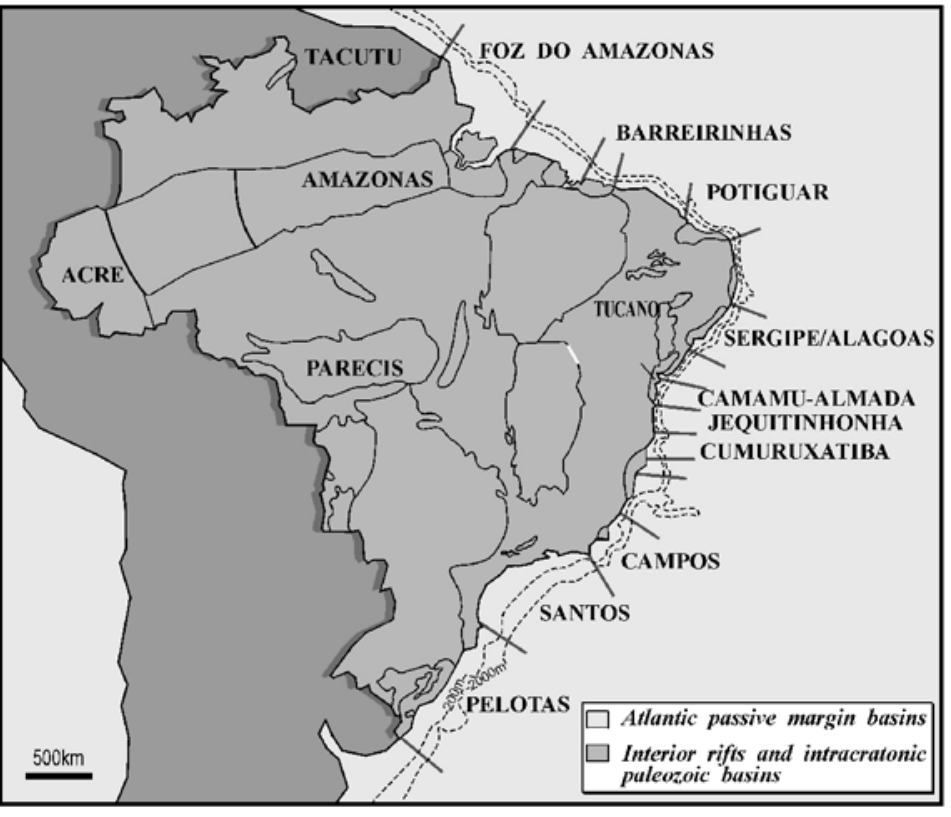

Figure 1 Location map of Brazilian sedimentary basins.

and Mohriak, 1998), is to provide a general overview of the tectonostratigraphic evolution of the sedimentary basins along the Eastern Brazilian Margin (Figure 1).

\section{Main morpho-structural elements}

Figure 2 shows the main physiographic features of the Brazilian continental margin. They are: (i) the spreading ridge between the South American and the African continents, located much closer to the coastline in the northern Brazilian basins, (ii) the approximate eastwest coastline along the equatorial transform margin, and (iii) the eastern Brazilian rift troughs with longitudinal axes more or less perpendicular to the Mid-Atlantic spreading ridge. Other important tectonic features are the Vitória-Trindade Chain, the Florianópolis Lineament, the Rio Grande Rise, and the São Paulo Plateau, which is characterized by a very large salt diapir province. In the deep water region, salt tectonics is responsible for mini-basins and evacuation troughs, expressed as seafloor irregularities, while volcanic plugs, (e.g., Almirante Saldanha Seamount) produce circular seafloor outlines. The largest E-W inflection along the Eastern Brazilian Margin occurs in the Rio de Janeiro State, between the Campos and Santos Basins (Figure 1). This E-W deflection of both the coastline and the pre-Aptian hinge line from the more general NE trend is marked, in the Cabo Frio province, by widespread post-rift volcanic activity 
with alkaline plugs dated from Late Cretaceous to Early Tertiary (Mohriak et al., 1990b). Northwards, the E-W Vitória-Trindade Chain corresponds to an important volcanic feature, probably associated with a hot-spot (Figure 2). There several submarine seamounts, adjacent to the Abrolhos Volcanic Complex and towards the abyssal plain, may reach the seafloor (e.g., Trindade and Martin Vaz Volcanic Islands). Several E-W or NW-SE lineaments correspond also to volcanic seamounts offshore Bahia, Sergipe and Alagoas states. Northeastern Brazil is characterized by the Recôncavo-TucanoJatobá Rift System which failed to develop a thermal phase of subsidence (Figueiredo et al., 1994), and by the elongated Jacuípe and Sergipe - Alagoas Basins, which correspond to rifts that evolved as continental margin sedimentary basins (Castro Jr., 1987). The platform in the northeastern margin is characterized by an abrupt shelf-break and by a continental/oceanic crust limit closer to the shelf-edge than at the southeastern region (Mohriak et al., 1995a).

Some of the features described above are expressed in the regional Bouguer anomaly map (Figure3), particularly the volcanic ridges, seamounts, and structural lineaments. This map also identifies the rift-phase depocenters (cold colors, from dark blue to light blue), the transitional crust (green), and the pure oceanic crust (hot colors, from red to violet).

\section{Structural and stratigraphic evolution}

The breakup of Western Gondwana started in the southern parts of the South American continent in the Late Jurassic/Early Cretaceous, and advanced towards the north, reaching the equatorial margin by Late Aptian/Early Albian (Rabinowitz and LaBrecque, 1979; Conceição et al., 1988; Chang et al., 1992; Matos, 1992). Early subsidence in the Brazilian territory is characterized in the aborted rifts in the onshore northeastern region (e.g., RecôncavoTucano-Jatobá rift system, Figure 1) by pre-rift sedimentation, whereas in the southeastern margin, these precursory phases of subsidence were filled by flood basalts both in the Paraná Basin and along the proto-Atlantic marginal basins (e.g., Pelotas, Santos and Campos basins, Figure 1). The subsequent phases of subsidence and sedimentation correspond to the continental, transitional and marine megasequences, which are analyzed in the context of sequence stratigraphy. The main structural and stratigraphic elements of the tectonic evolution of selected basins along the Eastern Brazilian margin are illustrated in Figure 4. Figure 5 shows the stratigraphic charts for the Santos, Campos and Sergipe/Alagoas Basins.

The stratigraphic framework of the Brazilian Continental Margin has been increasingly improved since the early seventies with the

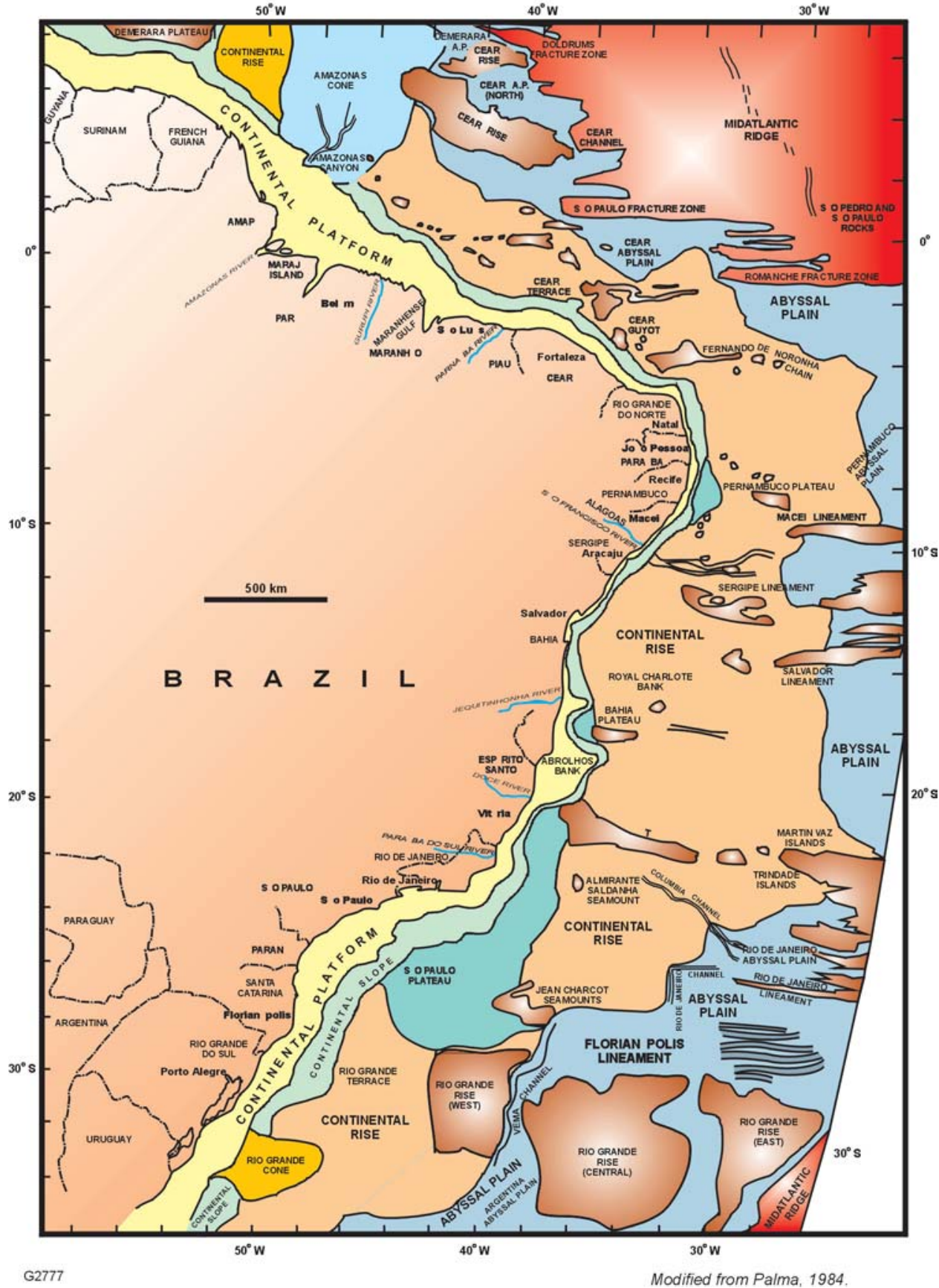

\section{Figure 2 Main geomorphologic structures of the Brazilian margin.}

advent of Plate Tectonics. Megasequences, normally separated by erosional unconformities, are intrinsically related to the major prerift, rift, and passive margin evolutional phases, which affect the Brazilian Continental Margin during its separation from the African Plate. The adopted stratigraphic framework accommodates tectonic phases with sequence stratigraphic principles hierarchically grouped in depositional megasequences, supersequences and sequences, as illustrated in the Santos, Campos, and Sergipe/Alagoas basins (Figure 5). We establish four megasequences: pre-rift, continental, transitional, and marine. The Pre-Rift Megasequence occurs only in the northeastern margin (both onshore and offshore) and was also subdivided into Paleozoic and Jurassic supersequences. The marine megasequence may be divided into restricted and open marine supersequences. 


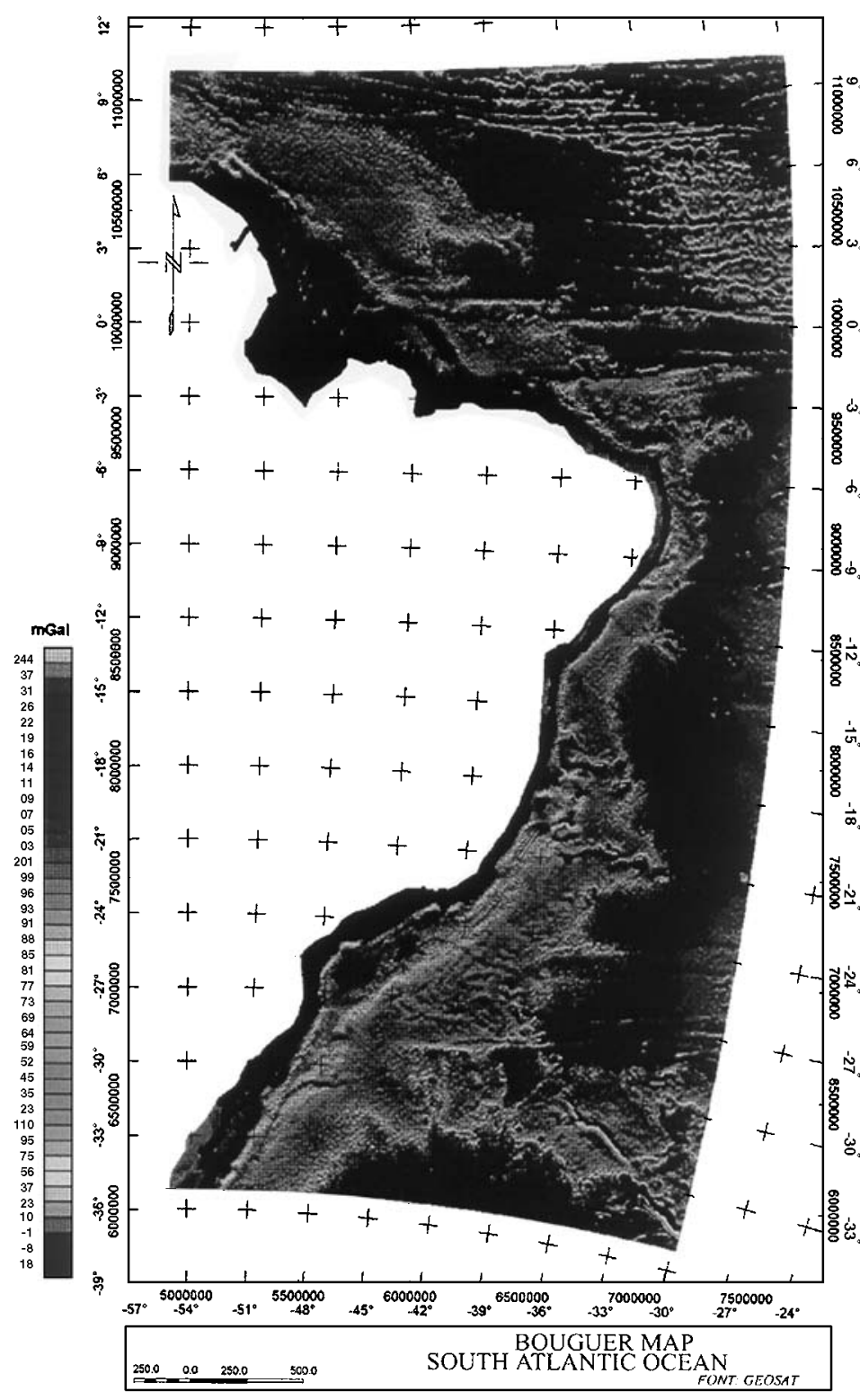

Figure 3 Bouguer map of the Brazilian margin, based on Geosat data.

\section{Pre-rift Megasequence}

It represents the intracratonic phase of the Gondwana Supercontinent, preceding the South American Rift and forming large and smooth sag basins. The Paleozoic Supersequence is notably developed in the large interior cratonic basins of Solimões, Amazon, Parnaíba, and Paraná (Figure 1). Paleozoic thickness may reach a few thousand meters in such basins, but in the Eastern Brazilian Margin it is mainly expressed as remnants of Permian and Carboniferous rocks in the Sergipe/Alagoas Basin, where it may reach hundreds of meters (Figure 5). The Jurassic Supersequence is separated from the Paleozoic Supersequence by an hiatus involving the entire Triassic. A new pulse of subsidence resulted in development of regional sags related to an early stretching which preceded the main rift phase and formed a larger basin that is designated as the palinspastic Afro-Brazilian Depression (Garcia, 1991; Chang et al., 1992). It may reach 100 to $300 \mathrm{~m}$ thick in Sergipe/Alagoas Basin, covering remnants of Paleozoic rocks or Precambrian basement (Feijó, 1994).

\section{Continental Megasequence}

$\overrightarrow{\vec{b}}^{\circ}$. It corresponds to main rift caused by the divergent motion of the African and South American tectonic plates in the Late Jurassic/Early Cretaceous. The Eastern Brazilian Rift, extending for $3,500 \mathrm{~km}$, is usually limited to the west by synthetic normal faults with variable displacements (exceeding 2,000 $\mathrm{m}$ in Campos and Sergipe/Alagoas Basins), or by hingelines with small offsets in Santos Basin (Figure 6). The delineation of the rift limit in the eastern direction is hampered by a degradation of seismic quality - near the transition from continental to oceanic crust, and its identification, which has important implications on petroleum exploration of deep water provinces, is based on multidisciplinary analysis integrating seismic, gravity, and magnetic data (Mohriak et al., 1995a; Bassetto et al., 1996).

The early syn-rift subsidence phases in elongated and faulted sags occur as thick packages of siliciclastic rocks registered between Espírito Santo and Sergipe/Alagoas Basins, while Santos and Campos Basins were occupied by tholeiitic basalts. This volcanic event, dated from 120 to $130 \mathrm{Ma}$, is time-equivalent to the

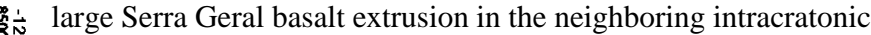
8araná Basin (Mizusaki et al., 1988; Zalán et al., 1990). The Continental Megasequence in most Eastern Atlantic sedimentary

$\frac{1}{\vec{\omega}_{0}}$ basins is faulted by a mosaic of N-S or NE/SW downstepping synthetic faults, sometimes interrupted by antithetic faults, filling a network of half-grabens with internal highs (Figure 6). It is composed of three main lithologic facies associations (Figueiredo, 1981; Dias et al., 1988): (i) alluvial fan/fan deltas and transitional ․ deposits, (ii) lacustrine marls and shales, and (iii) lacustrine pelecypod limestones (coquinas).

The proximal borders of the rift were dominated by alluvial $\dot{*}$. fan conglomerates and sandstones, where volcanic clasts were common components. A fine-grained facies developed in lacustrine depocenters where the extreme anoxic conditions in the Neo$\sim_{0}$ comian allowed the deposition of organic-rich, calcareous black shales, the main hydrocarbon source rock in the prolific Campos $\dot{\omega}$. Basin (Guardado et al., 1989; Mohriak et al., 1990c; Mello et al., 1994). Accumulations of pelecypod coquinas are best developed along the flanks and crests of rift internal highs, away from the input source of terrigenous sediments (Bertani and Carozzi, 1984; Bertani and Carozzi, 1985). Coquinas, besides fractured basalts, are the only producing hydrocarbon reservoirs of the rift phase in the Campos Basin while sandstones and conglomerates are the only ones in the Sergipe/Alagoas Basin. In the Santos Basin, the Continental Megasequence rapidly deepens basinwards, occurring at extreme depths, and is usually undrilled by exploratory boreholes (Figure 6). The upper temporal limit of rift faulting is bounded by the breakup unconformity (pre-Alagoas or pre-Aptian) that marks the onset of a tectonic quiescence, based on the paucity of faults and syntectonic activity during the deposition of sediments above it. The termination of the rift phase is diachronous along the Brazilian margin, ending in the southern segments by the early/middle Aptian, whereas in the northeastern segments, it may extend up to middle/late Albian times (Matos, 1992).

\section{Transitional Megasequence}

This megasequence marks the transition from the rifted Continental Megasequence below to the drift-phase Marine Megasequence above. The lithologic succession starts with Early Aptian siliciclastics and ends with evaporites spanning in age from Late Aptian to very Early Albian (Figure 6). The transitional phase is marked by the cessation of the stretching and rifting of the continental crust, and most basement-involved fault activity disappears. A period of peneplanization of the crests of uplifted and rotated Neocomian rift blocks was established, leaving a small residual topography (Figure 6). This erosional event, which probably corresponds to the breakup unconformity (Falvey, 1974), provided the siliciclastic source for coarse-grained Aptian sandstones and conglomerates deposited above the unconformity. Still in the Aptian, evaporites from the first 


\section{SEDIMENTARY BASINS ATLANTIC EASTERN BRAZILIAN MARGIN I}

\begin{tabular}{|c|c|c|c|c|c|c|c|}
\hline BASIN & $\begin{array}{l}\text { AREA } \\
(\mathrm{sq} \cdot \mathrm{km})\end{array}$ & $\begin{array}{l}\text { NORTHERN } \\
\text { LIMIT }\end{array}$ & $\begin{array}{l}\text { SOUTHERN } \\
\text { LIMIT }\end{array}$ & PRE-RIFT & $\begin{array}{l}\text { RIFT } \\
\text { TECTONICS }\end{array}$ & \begin{tabular}{l|} 
SALT \\
TECTONICS
\end{tabular} & $\begin{array}{l}\text { POST-RIFT } \\
\text { VOLCANISM }\end{array}$ \\
\hline PELOTAS & 210,000 & $\begin{array}{l}\text { Florianópolis } \\
\text { Platform }\end{array}$ & $\begin{array}{l}\text { territtorial } \\
\text { limit } \\
\text { (Uruguay) }\end{array}$ & $\begin{array}{l}\text { Paleozoic/ } \\
\text { Mesozoic } \\
\text { rocks } \\
\text { (Paraná } \\
\text { Basin) }\end{array}$ & $\begin{array}{l}\text { Early } \\
\text { Cretaceous } \\
\text { high-angle } \\
\text { antithetic faults }\end{array}$ & $\begin{array}{l}\text { absent to } \\
\text { incipient } \\
\text { (northem } \\
\text { part) }\end{array}$ & $\begin{array}{l}\text { volcanic } \\
\text { plugs near } \\
\text { the crustal } \\
\text { limit; } \\
\text { SDR wedges }\end{array}$ \\
\hline SANTOS & 206,000 & $\begin{array}{l}\text { Cabo Frio } \\
\text { Arch }\end{array}$ & $\begin{array}{l}\text { Florianópolis } \\
\text { Platform }\end{array}$ & $\begin{array}{l}\text { Early } \\
\text { Cretaceous } \\
\text { volcanics }\end{array}$ & $\begin{array}{l}\text { Early } \\
\text { Cretaceous } \\
\text { high-angle } \\
\text { antithetic/ } \\
\text { synthetic } \\
\text { faults }\end{array}$ & $\begin{array}{l}\text { very } \\
\text { intense } \\
\text { major } \\
\text { antithetic } \\
\text { faults }\end{array}$ & $\begin{array}{l}\text { Cabo Frio; } \\
\text { volcanic } \\
\text { plugs near } \\
\text { the crustal } \\
\text { limit, } \\
\text { SDR wedges }\end{array}$ \\
\hline CAMPOS & 100,000 & $\begin{array}{l}\text { Vitória } \\
\text { Arch }\end{array}$ & $\begin{array}{l}\text { Cabo Frio } \\
\text { Arch }\end{array}$ & $\begin{array}{l}\text { Early } \\
\text { Cretaceous } \\
\text { volcanics }\end{array}$ & $\begin{array}{l}\text { Early } \\
\text { Cretaceous } \\
\text { high angle, } \\
\text { low rotational } \\
\text { synthetic faults }\end{array}$ & $\begin{array}{l}\text { intense } \\
\text { major } \\
\text { synthetic } \\
\text { faults }\end{array}$ & $\begin{array}{l}\text { Cabo Frio; } \\
\text { volcanic plugs } \\
\text { near } \\
\text { the crustal limit, } \\
\text { SDR wedges }\end{array}$ \\
\hline $\begin{array}{l}\text { ESPIRITO } \\
\text { SANTO / } \\
\text { MUCURI }\end{array}$ & $\begin{array}{l}4,000 \\
\text { (onshore) } \\
46,000 \\
\text { (offshore) }\end{array}$ & $\begin{array}{l}\text { Abrolhos } \\
\text { Volcanic } \\
\text { Complex }\end{array}$ & $\begin{array}{l}\text { Vitória } \\
\text { Arch }\end{array}$ & $\begin{array}{l}\text { Early } \\
\text { Cretaceous } \\
\text { volcanics }\end{array}$ & $\begin{array}{l}\text { Early } \\
\text { Cretaceous } \\
\text { high angle, } \\
\text { low rotational } \\
\text { synthetic faults }\end{array}$ & $\begin{array}{l}\text { reduced } \\
\text { onshore; } \\
\text { intense in the } \\
\text { platform; } \\
\text { very intense } \\
\text { in deep } \\
\text { waters }\end{array}$ & $\begin{array}{l}\text { Abrolhos; } \\
\text { Royal Charlotte }\end{array}$ \\
\hline $\begin{array}{l}\text { SERGIPE/ } \\
\text { ALAGOAS }\end{array}$ & $\begin{array}{l}13,000 \\
\text { (onshore) } \\
20,000 \\
\text { (offshore) }\end{array}$ & $\begin{array}{l}\text { Maragogi } \\
\text { High }\end{array}$ & $\begin{array}{l}\text { Jacuípe } \\
\text { High }\end{array}$ & $\begin{array}{l}\text { Paleozoic/ } \\
\text { Mesozoic } \\
\text { rocks }\end{array}$ & $\begin{array}{l}\text { Early } \\
\text { Cretaceous } \\
\text { low-angle, } \\
\text { high rotational } \\
\text { synthetic faults }\end{array}$ & $\begin{array}{l}\text { reduced } \\
\text { onshore; } \\
\text { weak in the } \\
\text { platform; }\end{array}$ & $\begin{array}{l}\text { volcanic } \\
\text { plugs near } \\
\text { the crustal } \\
\text { limit, } \\
\text { SDR wedges }\end{array}$ \\
\hline
\end{tabular}

Figure 4 Chart showing main tectono-stratigraphic features of some of the sedimentary basins in the Brazilian margin.

marine ingressions invaded the elongated South Atlantic Gulf, with deposition of halite and anhydrite (Asmus and Ponte, 1973). Evaporites occur both in South America and West Africa, from the Rio Grande Fracture Zone in the south, to the Pernambuco Lineament in the north. Salt movements, affecting the overlying rocks, created a series of listric growth faults in the evacuation zones, intraslope subbasins surrounded by piercing salt domes, salt walls, and thrust faults (Cobbold et al., 1995). Two end-member styles of salt tectonics are recognized in the South Atlantic (Mohriak, 1995; Mohriak et al., 1995b). In the Campos Basin, most faults related to salt tectonics are synthetic (basinward-dipping), creating rafts of Albian blocks that move basinwards (Figure 7). In the Santos Basin, a peculiar style of salt tectonics associated with massive clastic progradation is illustrated in Figure 8. These prograding wedges of Upper Cretaceous to Early Tertiary sediments show depocenters that become younger basinwards, as the result of salt mobilization by the sedimentary loading, which was controlled by an antithetic (landward-dipping) fault that detaches at the base of the salt, resulting in large stratigraphic gaps (Mohriak et al., 1995b).

The Transitional Megasequence plays an important role as the main horizontal carrier bed for hydrocarbons generated from continental and transitional source rocks in the Campos and Sergipe/Alagoas Basins (Mello et al., 1994). Additionally, it controls the oil distribution into the Marine Megasequence through the upward oil migration in listric faults, and also the facies distribution of the overlying carbonates and sandy turbidites. They were structured by underlying salt movements through salt pillows, piercing diapirs and salt walls, forming a series of combined structural and stratigraphic traps (Figueiredo and Mohriak, 1984).

\section{Marine Megasequence}

The passage from the evaporitic Transitional Megasequence to the Marine Megasequence is gradational, punctuated by minor subregional unconformities. The decay of the thermal anomaly created during the stretching phase (Mckenzie, 1978) and the progressive movement away from the mid-ocean ridge by Brazil and Africa caused the cooling and contraction of the lithosphere, resulting in increasing thermal subsidence offshorewards. The continuous subsidence started to dissipate the restriction barriers of the South Atlantic Ocean. Part of the Marine Megasequence, spanning from Early Albian to Late Cenomanian, is still marked by hypersaline and anoxic conditions (Dias-Brito, 1982; DiasBrito, 1987). Increasingly open marine conditions started to prevail only by Late Turonian times. These environmental changes were used to subdivide the megasequence into a shallow water carbonate Restricted Marine Supersequence and a siliciclastic Open Marine Supersequence with environments that reached bathyal to abyssal depths (Dias-Brito and Azevedo, 1986).

The Restricted Marine Supersequence is also subdivided, based on environmental and lithologic characteristics, in Neritic, Hemipelagic and Deepening sequences. The Neritic Sequence, spanning from Early to Middle Albian, was marked by a high energy, shallow water carbonates, deposited in a ramp/platform setting. It was overlain by the Hemipelagic and Deepening sequences, spanning the Late Albian to Turonian, and represent the drowning of the platform, coinciding in time with an anoxic event that affected the entire South Atlantic Ocean (Schlager, 1981; Schlager, 1989). These younger sequences are composed of calcilutites, marls and sand-rich turbidites, deposited in deep neritic to bathyal conditions (Cainelli et al., 1985; Esteves et al., 1987; Guardado and Spadini, 1987; and Guardado et al., 1989). The Neritic Sequence constitutes the base of the Restricted Marine Supersequence, and can reach more than 1000 meters. It is formed mainly by calcarenites and dolomites, developed in warm and dry weather on shallow neritic setting with hypersaline water and oxygenated bottom (Dias-Brito, 1982; Dias-Brito and Azevedo, 1986; Koutsoukos and Dias-Brito, 1987; Azevedo et al., 1987). The general coincidence among salt pillows and elongate NESW-trending high energy shoals (Figure 9) suggest that their development was controlled by the positive features (pillows) created by salt tectonics, while fine-grained carbonates occupied the depressions between the shoals (Guardado and Spadini, 1987; Esteves et al., 1987). The Hemipelagic and Deepening sequences represent the 


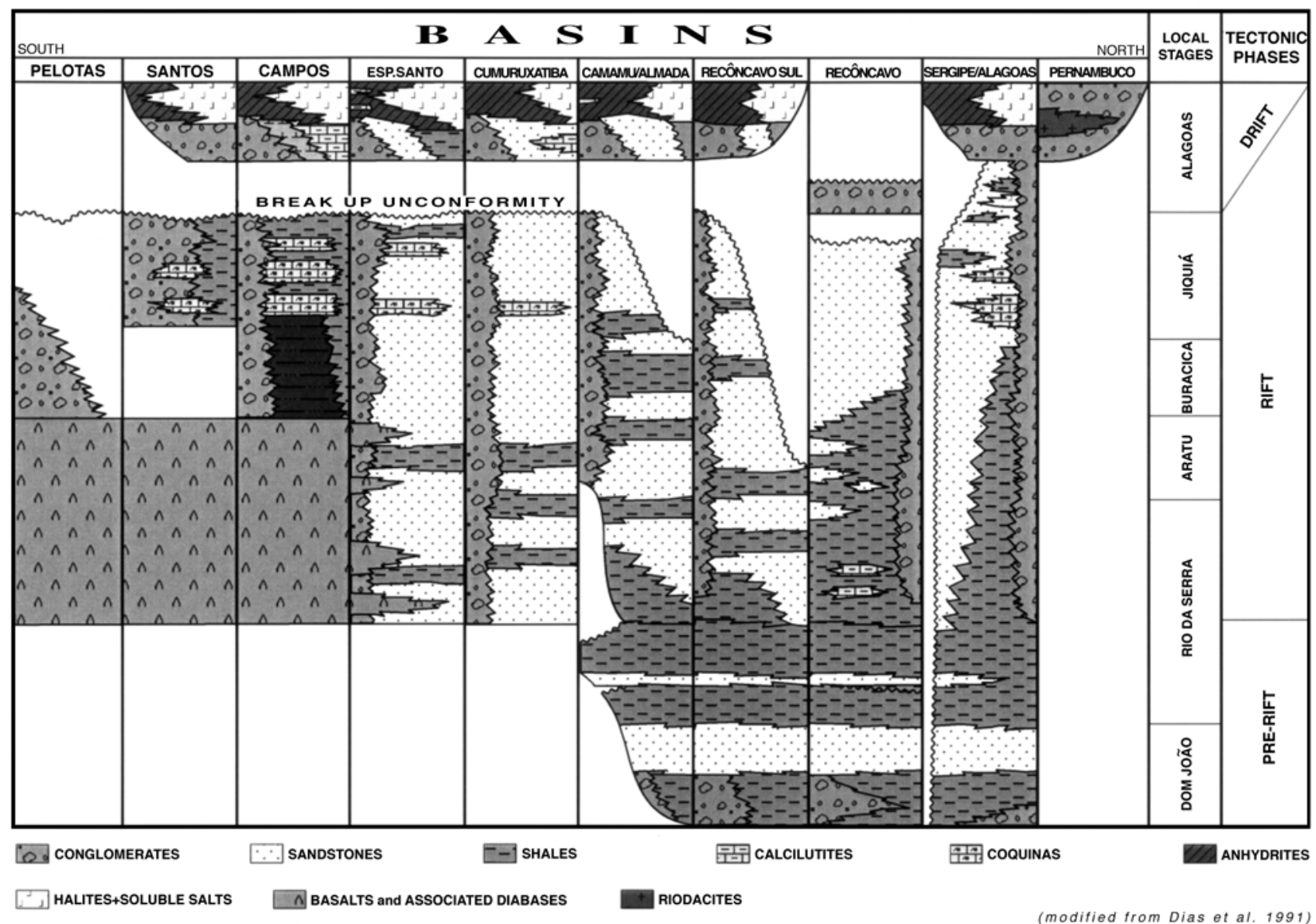

Figure 5 Stratigraphic columns of the Santos, Campos and Sergipe-Alagoas sedimentary basins.

demise of the late Cretaceous shallow water carbonates in the Eastern Brazilian Margin and culminated with the deposition of organicrich black shales, related to the worldwide anoxic event in Cenomanian/Turonian times. The sequences may reach thickness of 100 to $600 \mathrm{~m}$ (or even greater in the deepwater region), and are formed by calcilutites interbedded with marls and shales. Turbidite sandstones are distributed throughout the sequences, and indicate thirdand fourth-order relative sealevel falls in the prevailing second-order relative sea level rise. The Albian turbidites in the Campos Basin form extensive blankets, meanwhile the Cenomanian/Turonian turbidites were confined into narrow fault-controlled troughs in response to the initiation of an intense phase of halokinesis (Figueiredo and Mohriak, 1984; Guardado et al., 1989).

The Open Marine Supersequence marks the truly oceanic phase of deposition in the eastern Brazilian basins, characterized by relative environmental stability and a greater biological diversification with paleowater depths reaching values around 1000 to $2000 \mathrm{~m}$ in the present-day platform (Koutsoukos, 1984; Koutsoukos, 1987). The infilling histories are similar in Campos and Sergipe/Alagoas Basins, characterized by a general late Cretaceous retrogradational style, followed by Tertiary progradational style with offlapping sequences (Figure 7). Conversely, in the Santos Basin (Figure 8), the larger amounts of sediments supplied by the Serra do Mar mountain range uplift exceeded the space accommodation created by the sea level rise and established a general prograding section, deposited mainly during the Campanian/Maastrichtian interval (Pereira et al., 1986; Pereira and Feijó, 1994). The prograding section advanced several dozens of kilometers basinward of the shelf-edge. In the adjacent Campos Basin, a smaller influence of the Serra do Mar uplift allowed the deposition of transgressive shales that advanced several dozens of kilometers landward from the present-day shelf edge (Guardado et al., 1989; Dias et al., 1990)

During the Late Cretaceous and Early Tertiary, igneous plugs intruded the oceanic and continental crust along oceanic fracture zones and lineaments. Figure 10 illustrates one of these features along the Southern Cross Lineament, which extends along a NW trend from the oceanic crust towards the Cabo Frio region at the border between the Campos and Santos Basins (Souza et al., 1993). The Jean Charcot seamounts occur basinwards of the salt limit, in the transition from continental to oceanic crust, and the Rio Grande fracture zone extends along the E-W direction from oceanic crust towards the Florianópolis platform (Severino and Gomes, 1991).

A greater sediment input into a progressively smaller accommodation space produced a well-defined offlapping shelf-slopebasin wedge during the Upper Tertiary, reaching more than 3,500 meters in thickness (Figure 6). A mixed clastic-carbonate shelf margin was established, with coastal/shelf sandstones grading seaward into rimmed carbonates along the shelf edge (Figures 5 and 6). Turbidite lenses occur extensively in the Early Tertiary, particularly above a Middle Eocene unconformity that is widespread in the Campos Basin (Rangel et al., 1994). A large turbidite complex was established during the Oligocene, formed by three main turbidite systems, genetically related to sequence boundaries (Dias et al., 1990; and Carminatti and Scarton, 1991). Entire areas of the outer shelf and 
$N W$

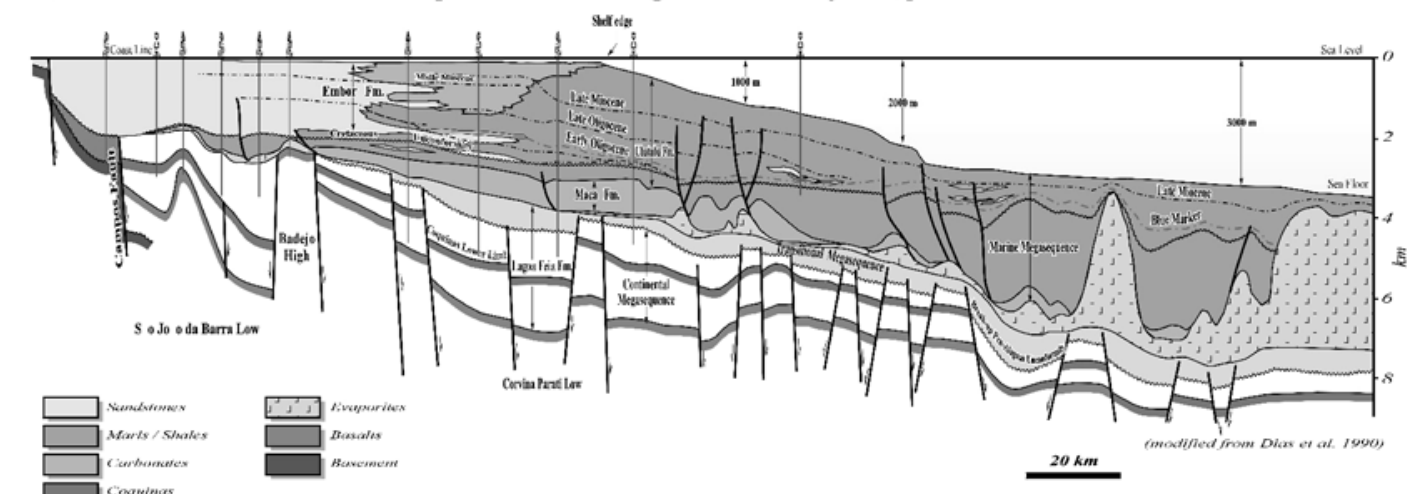

Dip-Oriented Geolog

$N W$

Dip-Oriented Geological Section of Santos Basin

SE

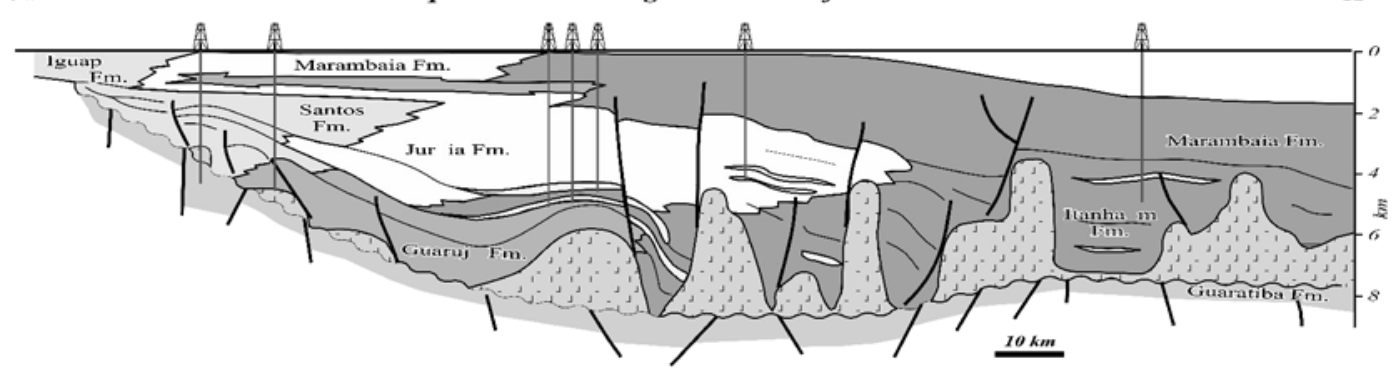

Figure 6 Schematic dip-oriented geological sections in the Campos and Santos Basins.

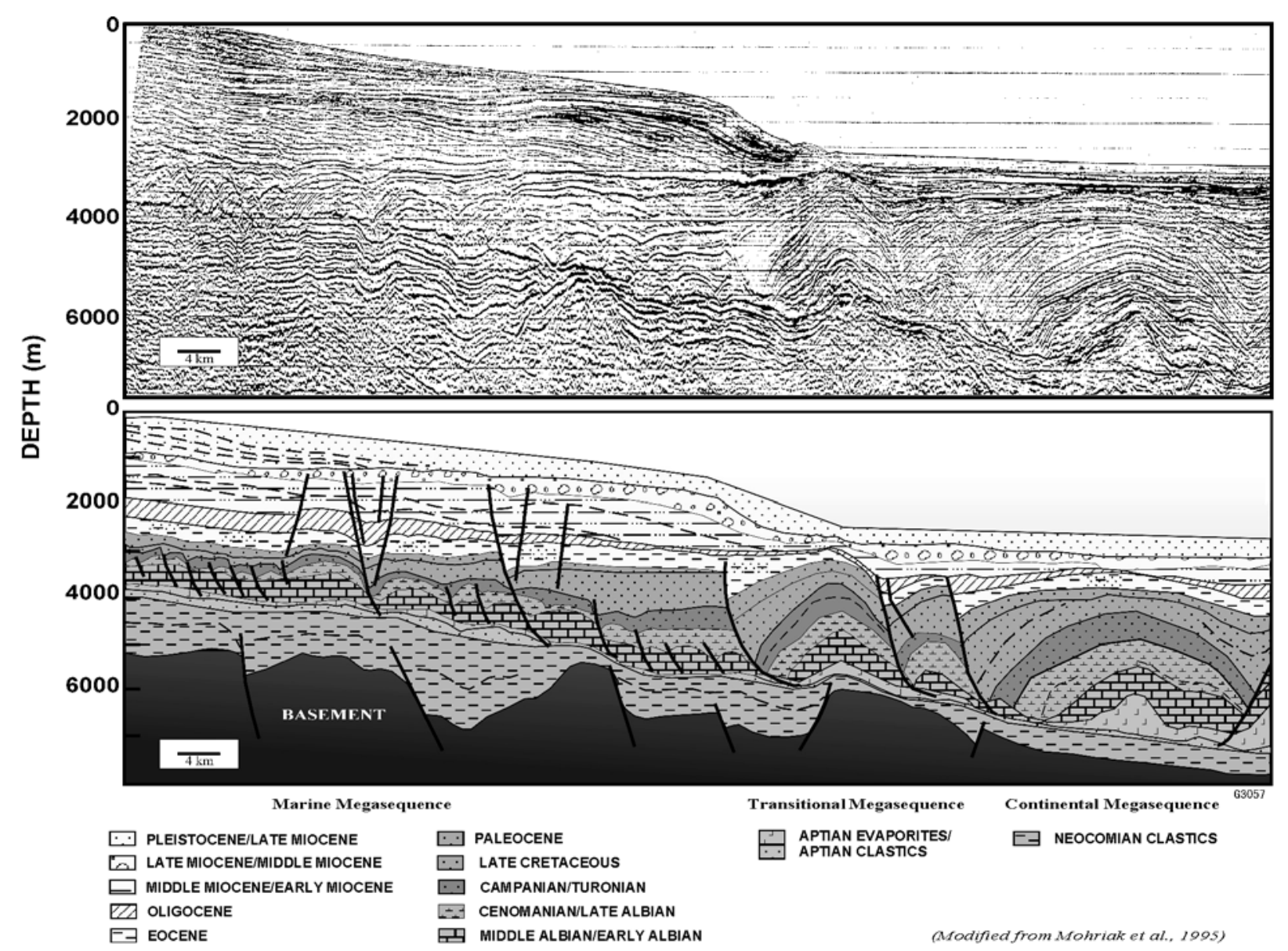

Figure 7 Seismic section of the Campos Basin. 


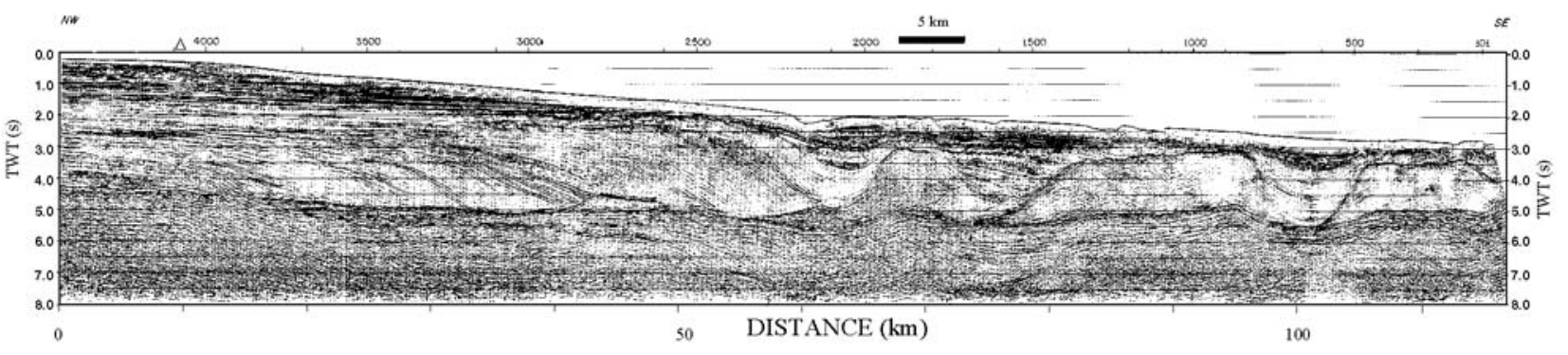

$N W$

$S E$

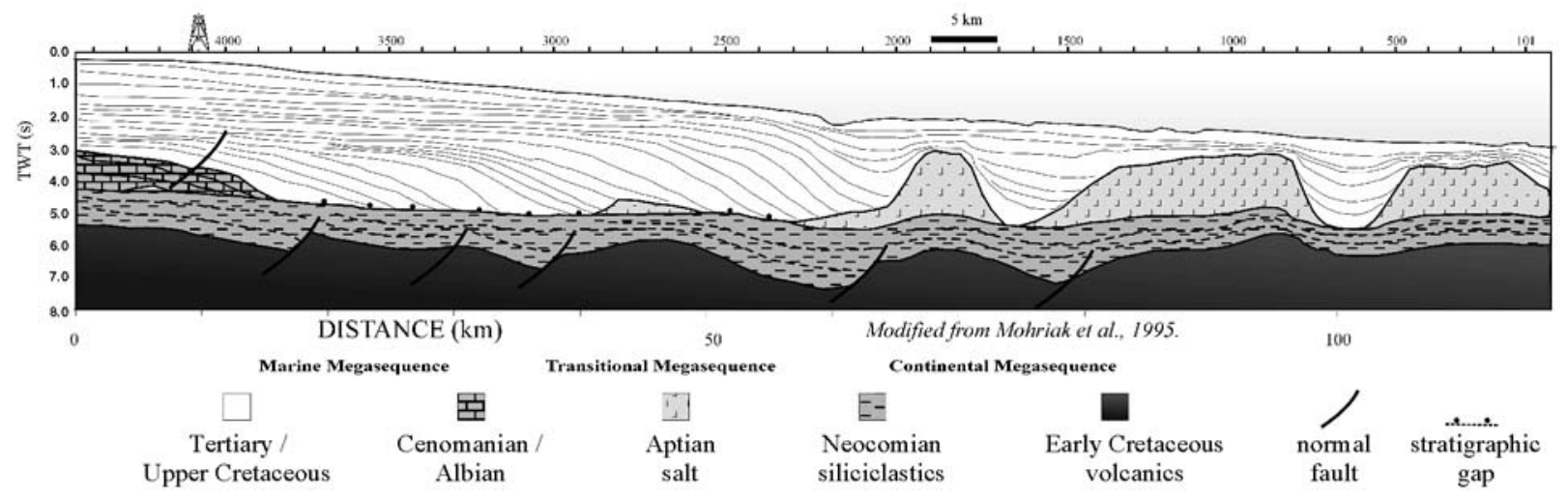

Figure 8 Seismic section of the Santos Basin.
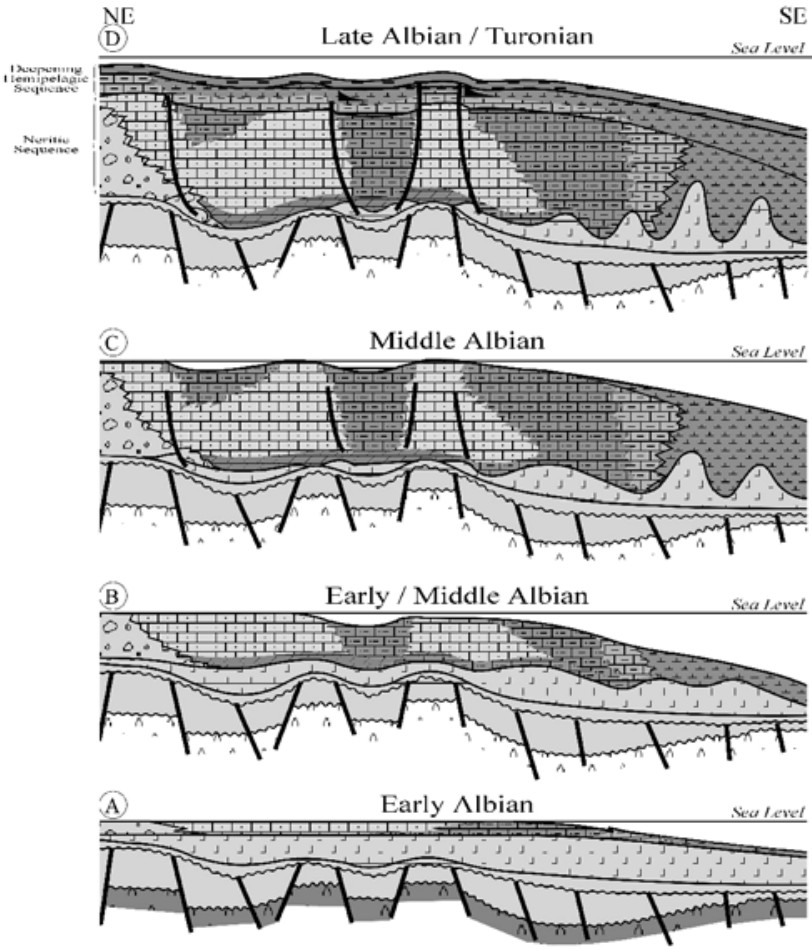

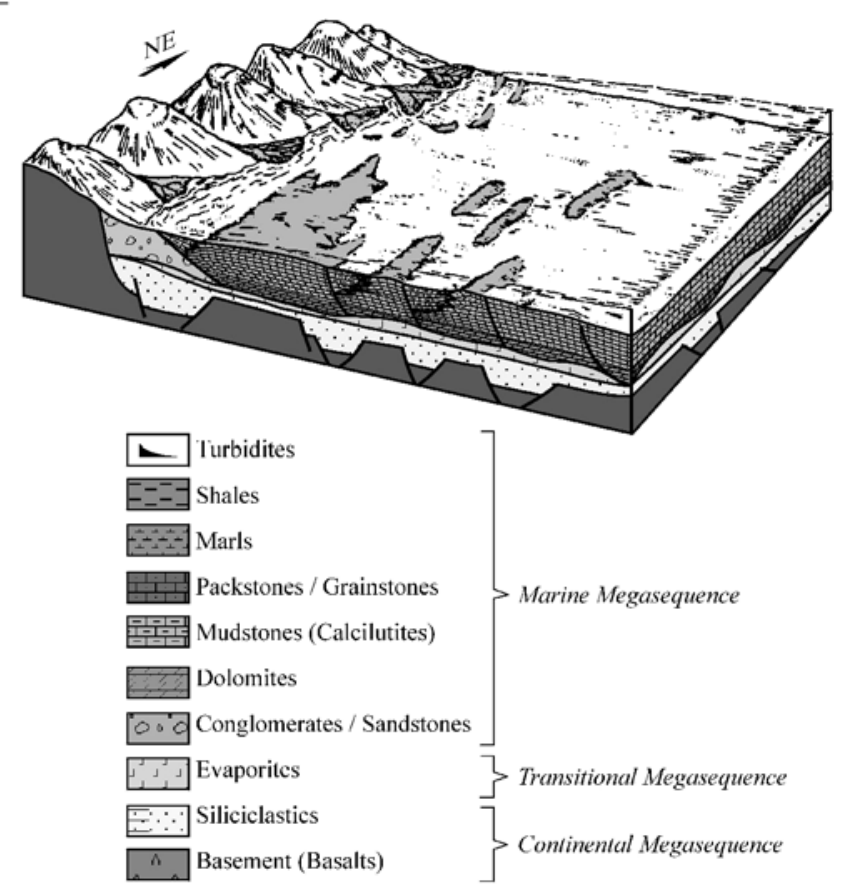

Figure 9 Evolutive geological section and schematic block diagram showing the evolution of the Restricted Marine Supersequence. 

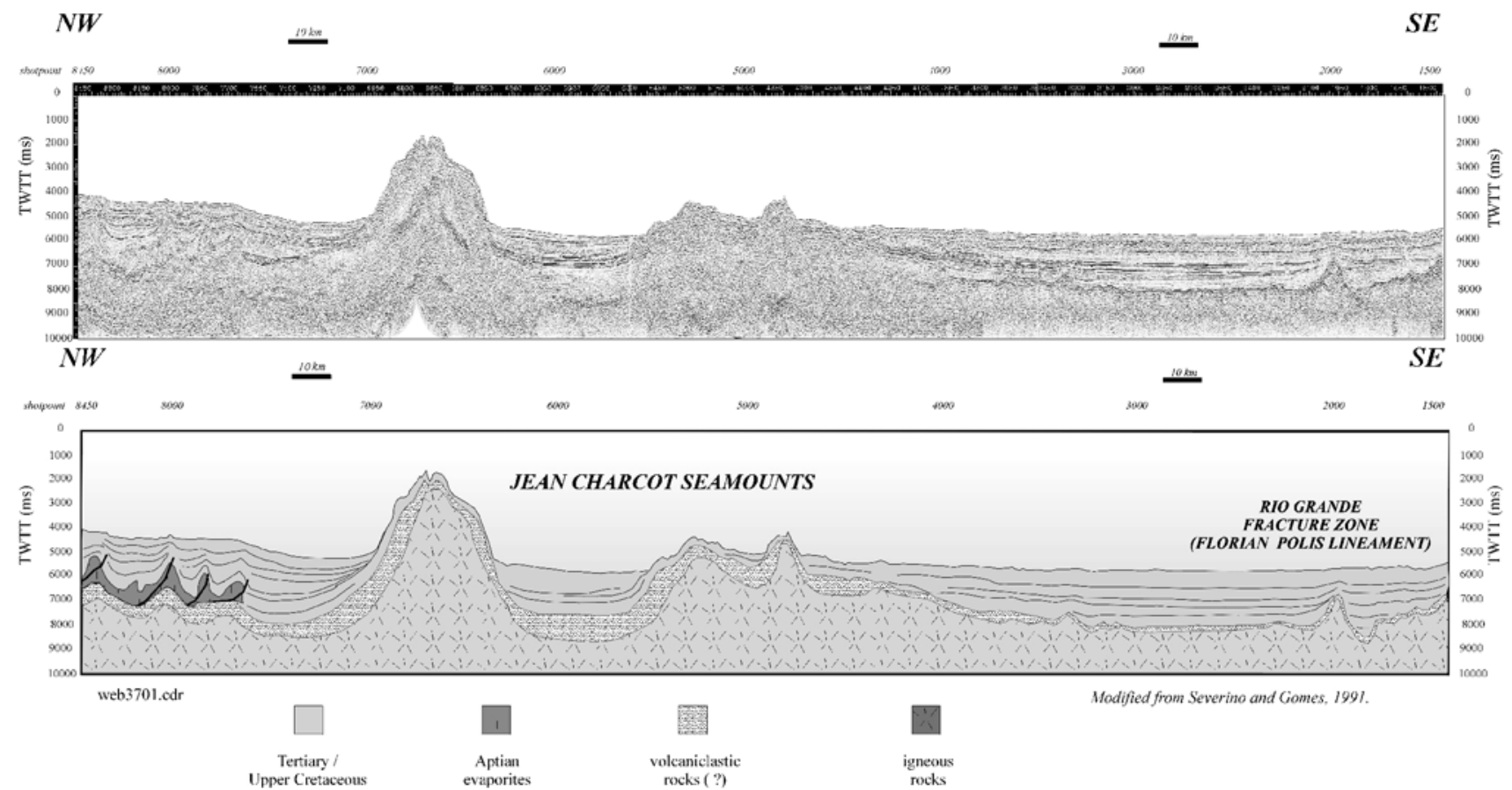

Figure 10 Jean Charcot Seamount in the deep water region of the São Paulo Plateau (Santos basin).

slope became unstable, triggering huge volume transference of sediments basinwards, as gravity mass-flow deposits, mainly turbidites and debris flows (Peres, 1993). The erosional portion of each sequence boundary is expressed seismically by incised valleys, canyons, scars and slope failures (Carminatti and Scarton, 1991; Cainelli, 1994). Basinwards, the thickest turbidite deposits accumulated where salt remobilization occurred contemporaneously with deposition in response to the differential sedimentary load. This process provided a wide, shallow depression, which continued to focus the deposition of successive turbidity systems that amalgamated vertically and coalesced laterally to form a relatively thick and extensive blanket-like apron (Figure 11). Later on, more than $1000 \mathrm{~m}$ of pelitic Miocene sediments covered this Oligocene turbidite complex. This resulted in renewed loading over the salt layers with development of huge listric faults, which structured the Oligocene turbidites and created pathways for upward oil migration. Data from the Marlin and Albacora giant fields (Souza Cruz, 1995) reveals three main lithofacies for the Oligocene turbidite system. Proximal deposits are characterized by massive shaly conglomerates and pebbly sandstones, forming residual channel lags or infilling irregular or erosional surfaces. The second facies consists of fine-grained, structureless sandstones, ranging in thickness from 30 to 150 meters (Figure 11). The third facies is characterized by intercalations of well-sorted, laminated sandstones, product of winnowing and reworking by bottom currents, and hemipelagic shales. The latter two facies comprise more than $95 \%$ of the Oligocene reservoirs of the Marlin and Albacora giant oil fields (Carminatti and Scarton, 1991). The seismically tabular sand body reveals a greater complexity on the oil field scale (Martins et al., 1995), indicating that these turbidites are formed by (i) channel complexes, (ii) thicker, amalgamated lobes, and (iii) thinner, amalgamated lobes heavily dissected by channels (Bruhn et al., 1998). In the Sergipe/Alagoas Basin, Late Cretaceous/Early Tertiary

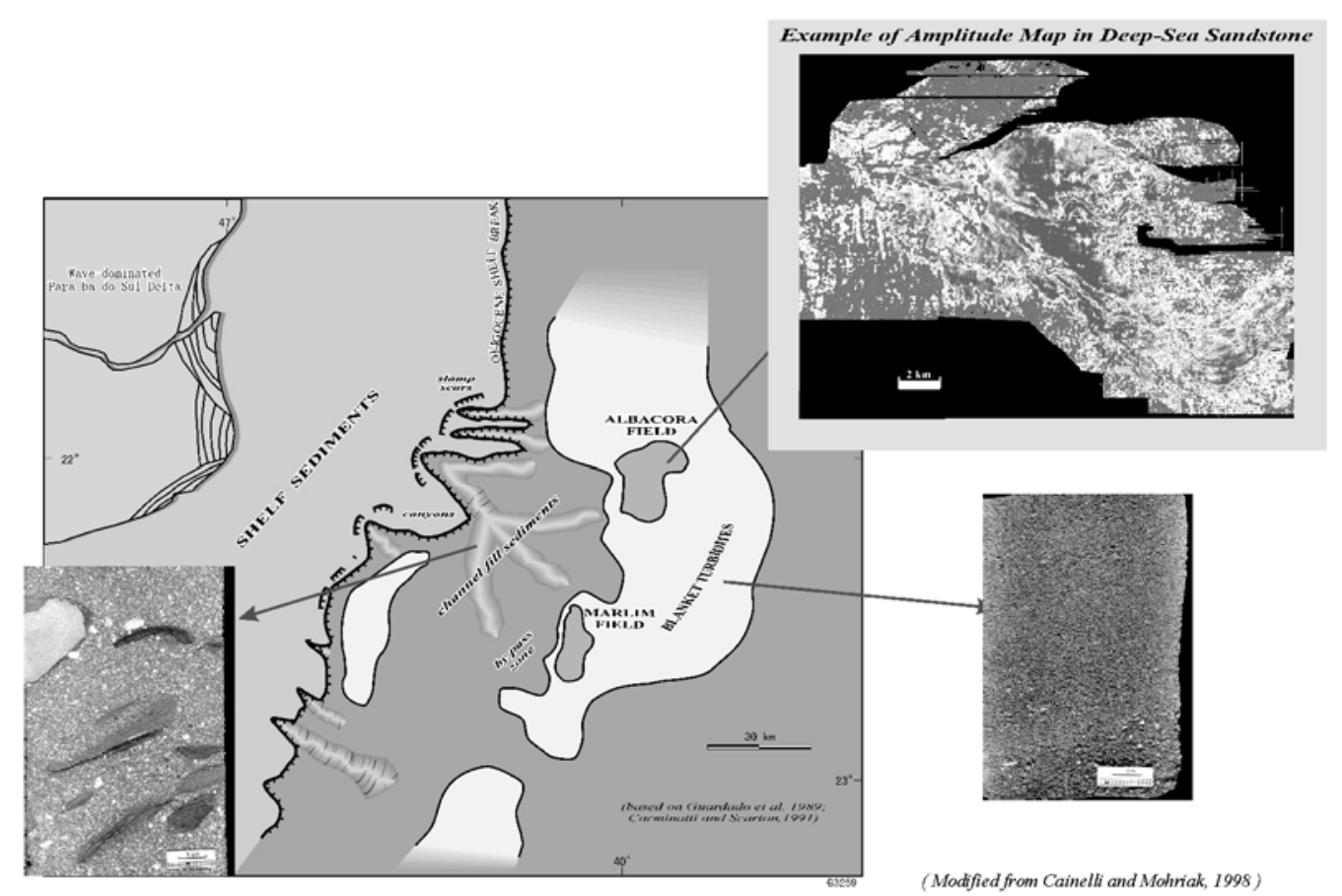

Figure 11 Paleogeographic map of deep-sea turbidite with example of amplitude anomaly map of the Albacora giant oil field in the Campos Basin and cores. 
sandy turbidites are a common and serendipitous event when drilling for deeper targets. Normally the sandstone layers are thin, reaching only a few dozen-meter thickness. They were interpreted as coarsegrained lags in isolated or amalgamated, migrating leveed channels in a slope apron environment (Cainelli, 1992). In the Santos Basin, large turbidite systems can be identified from the platform towards the deep-water region (Pereira et al., 1986; Peres, 1993; Cainelli and Carminatti, 1994).

\section{Geodynamic Evolution}

The study of the tectono-sedimentary evolution of the sedimentary basins in the South Atlantic is greatly improved by analyzing conceptual models based on observations from several other passive margin sedimentary basins worldwide. These basins are characterized by an evolutive sequence with both similarities and differences when one compares diverse provinces or even segments along the margin. But, in general, the evolution of these basins follows a sequence of events that have allowed the proposition of geodynamic models in the context of plate tectonics that may be useful in regional basin analysis.

The sequential evolution of the South Atlantic is marked by five main phases with different patterns of tectonics and sedimentation

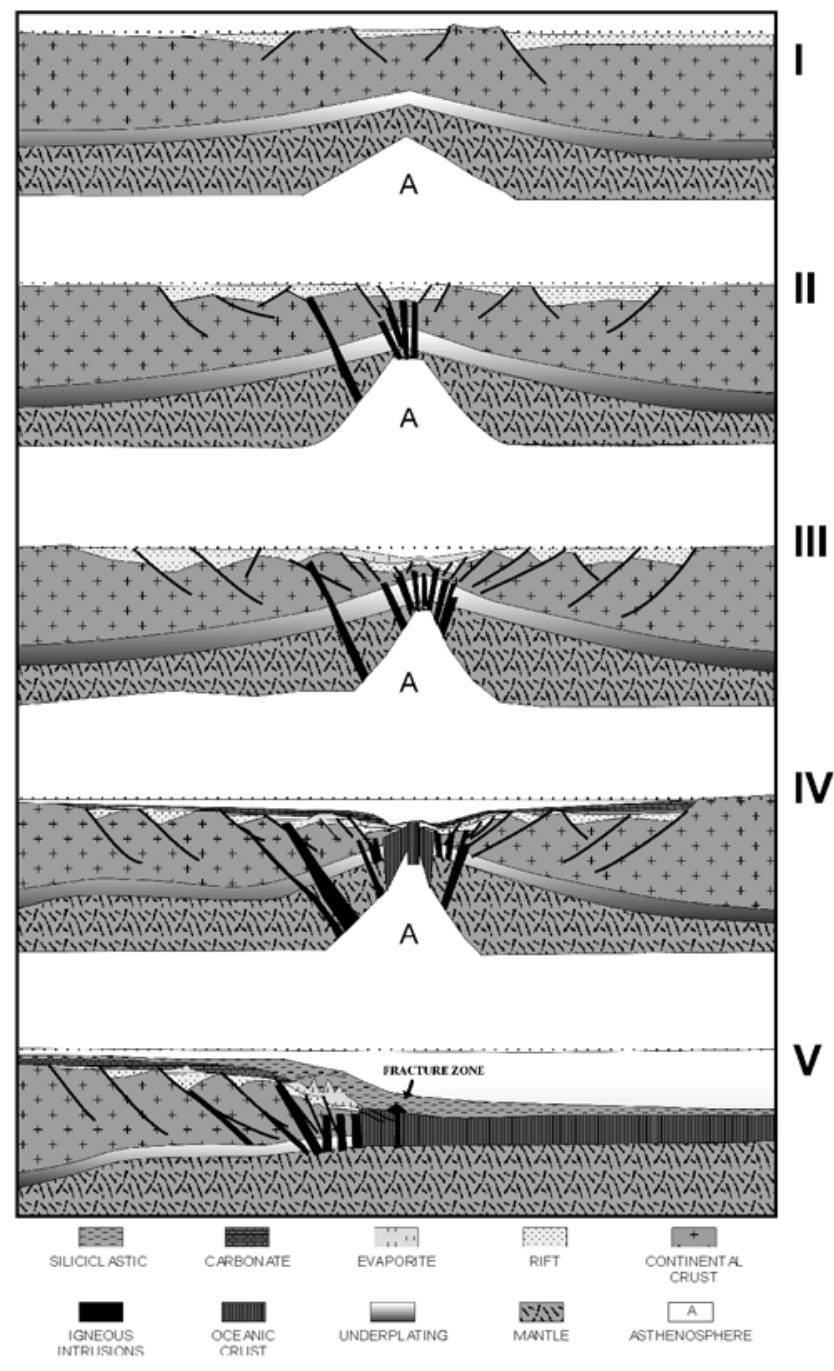

Figure 12 Schematic geodynamic model of the South Atlantic evolution.
(Figure 12). The first phase is marked by the beginning of extensional processes, which led to the separation of the South American and African continents. The conceptual model for this phase admits a small asthenospheric uplift and regionally distributed thinning of the continental crust and upper mantle, with incipient faults in the upper crust controlling local depocenters associated with widespread, thin sedimentary sequences (Figure 12-I). The beginning of the next phase, which is characterized by increasing lithospheric stretching, coincides with large faults affecting the continental crust, extrusion of continental flood basalts in the southern basins, and formation of half-grabens (Figure 12-II). By the end of the rifting episode, there is an increase in the lithospheric extension that is marked by large faults which rotate the rift blocks and the sedimentary layers previously deposited (Figure 12-III). The mid-Atlantic Ridge responsible for inception of oceanic crust probably intruded the crust by the end of the rifting episodes, and in some basins, it is associated with subaerial volcanism responsible for the thick wedges of seaward-dipping reflectors observed in seismic profiles (Hinz, 1981; Mutter, 1982; Mutter et al., 1985; Mohriak et al., 1998). The possible mechanism for this episode involves focusing of the lithospheric stretching, previously distributed in a wider region, to a locus in the region of the mid-Atlantic Ridge (Harry and Sawyer, 1992). This phase is associated with continental and oceanic volcanism, reactivation of large faults, and erosion of rift blocks by a regional unconformity that levels the topography, separating continental from transitional to marine environments of deposition (Figure 12-IV). Above this unconformity and below the evaporite transitional sequence, some sedimentary basins register a substantial thickness of Aptian sediments, which locally may give rise to petroleum source rocks (Henry and Brumbaugh, 1995). Subsequently to the salt deposition in the Aptian, sedimentation becomes predominantly carbonatic. An increase in the bathymetry resulted in the deepening of the environment of deposition by the end of the Albian, with demise of the shallow water carbonates (Figure 12-V).

\section{Conclusions}

The tectono-stratigraphic evolution of the eastern Brazilian sedimentary basins is consequence of the onset and full development of the South Atlantic Ocean. The breakup of Western Gondwana in the Mesozoic started with rifting in the southernmost part of South America, and is characterized by extrusion of flood basalts in the Paraná Basin and along the southeastern Brazilian margin rift basins. The aborted rifts in the onshore northeastern region of Brazil (e.g., Recôncavo-Tucano-Jatobá) are devoid of these volcanics, but the deep water extension of the Sergipe/Alagoas Basin is characterized by seaward-dipping reflectors. The syn-rift phase is characterized by synthetic and antithetic faults forming several half-grabens whose trend is more or less parallel to the present-day coastline, filled by siliciclastic fluvio-deltaic sediments with local development of pelecypod coquinas. Rifting age shifted gradually from Neocomian in the southern basins to Aptian and even Albian in the northeasternmost basins. The Transitional Megasequence is characterized by a tectonic quiescence with Aptian evaporite deposition with the development of diapirs, salt walls, and intraslope mini-basins in deep water. A coarse-grained siliciclastic wedge between the breakup unconformity and the salt base constitutes the main horizontal carrier bed from rift-sourced hydrocarbons to post-salt reservoirs. The oceanic crust inception was heralded by massive volcanic flows forming thick wedges of seaward-dipping reflectors. The drift phase was initially characterized by a shallow water carbonate sedimentation that gradually changed to a deep-water siliciclastic sedimentation. Salt-related listric faults are the main vertical migration pathways towards Albian-to-Tertiary reservoirs. Upper-Cretaceous and Tertiary sand-rich turbidites of the Open Marine Megasequence are presently responsible for most of the hydrocarbon production and reserves in the offshore basins. These deepwater reservoirs are arranged, in general, in a retrogradational infilling style in Upper 
Cretaceous successions, and are usually followed by a well-defined progradional style during Tertiary times.

\section{Acknowledgements}

We thank Petrobras for permission to publish this review. Although the final integration and synthesis of concepts remain an entirely responsibility of the authors, this article has greatly benefited by ideas developed in the last two decades by many Petrobras explorationists in dozens of published articles, internal company reports, and seminars. We apologize to all those people whose contributions could not be appropriately cited in the references. We are also grateful to many individuals for enlightening informal discussions or personal communications in the past decades, which helped to improve our perception about the Brazilian geology.

\section{Cited references}

Asmus, H.E. and F.C. Ponte, 1973, The Brazilian Marginal Basins in The Ocean Basins and Margins, v.1 - The South Atlantic, Nairn, A.E.M. and F.G. Stehili, eds, Plenum Press, Nova York, p.87-133.

Azevedo, R.L.M., J. Gomide, andM.C. Viviers, 1987, Geohistória da Bacia de Campos, Brasil, do Albiano ao Maestrichtiano: Revista Brasileira de Geociências, v.17, p.139-146.

Bassetto,M.,W.U.Mohriak, and I.S. Vieira, 1996,Modelagens Gravimétrica e Magnética Utilizadas como Ferramentas de Apoio á Análise Regional de Bacias Sedimentares: XXXIX Congresso Brasileiro de Geologia,v.5,p. 222-225

Bertani, R.T., and A.V. Carozzi, 1984, Microfacies, Depositional Models and Diagenesis ofLagoa Feia Formation (Lower Cretaceous) Campos Basin, Offshore Brazil: Ciência-Técnica-Petróleo, Petrobras Cenpes, v.14, p.104.

Bertani, R.T., and A.V. Carozzi, 1985, Lagoa Feia Formation (Lower Cretaceous) Campos Basin, Offshore Brazil: Rift-valley Stage Carbonate Reservoirs - I and II: Jounal of Petroleum Geology, v.8, 37-58, p.199220.

Bruhn C.H.L., M.R. Becker, L.M. Arienti, E.B. Rodrigues, C.E.B.S. Abreu, R.R.P. Alves, D.D. Castro, R.A. Santos, L.C.S. Freitas, A. P. Barros, and D.J. Sarzenski, 1998, Contrasting Styles of Oligocene/Miocene Turbidite Resevoirs from Deep Water Campos Basin, Brazil: Proceedings for the 1998 AAPG Annual Convention, Salt Lake City, Utah (USA), A95, 4p.

Cainelli, C., 1992,Sequence Stratigraphy, Canyons, and Gravity Mass Flow Deposits in the Piaçabuçu Formation, Sergipe/Alagoas Basin, Brasil., Ph.D thesis, University of Texas at Austin, USA, 233p.

Cainelli, C., 1994, Shelf processes and canyon/channel evolution controlling turbidite systems: examples from the Sergipe/Alagoas Basin, Brazil, GCSSEPM Foundation Fifteenth Annual Research Conference, Submarine fans and turbidite systems, p. 39-50.

Cainelli C.,N.A. Babinski, R.C.Santos, and N. Uesugui, 1985, Sedimentos Albo-Santonianos da Bacia de Sergipe-Alagoas: Ambientação e Perspectivas Petrolíferas: IX Congresso Brasileiro de Paleontologia.

Cainelli C., and M. Carminatti, 1994, Seismic Criteria to Recognize Potential Deep-Sea Sandstones in Brazilian Passive Margin Basins (abs): AAPG Bulletin.

Cainelli, C. and Mohriak, W.U., 1998. Geology of Atlantic Eastern Brazilian basins. 1998 AAPG International Conference \& Exhibition Short Course - Brazilian Geology Part II, November 8-11, Rio de Janeiro, Brazil.

Carminatti, M., and J.C. Scarton, 1991, Sequence Stratigraphy of the Oligocene Turbidite Complex of the Campos Basin, Offshore Brazil: an Overview, in Weimer, P., and M.H. Link, eds, Seismic Facies and Sedimentary Processes of Submarine Fans and Turbidite Systems, SpringerVerlag, New York, p.241-246.

Castro Jr., A.C.M., 1987, The Northeastern Brazil and Gabon Basins: a Double Rifting System Associated with Multiple Crustal Detachment Surfaces: Tectonics, 6, p.727-738.

Chang, H. K., R.O. Kowsmann, A.M.F. Figueiredo, and A. Bender, 1992, Tectonics and Stratigraphy of the East Brazil Rift System: an Overview: Tectonophysics 213, p. 97-138.

Cobbold, P.R., P. Szatmari, L. S. Demercian, D. Coelho, and E.A. Rossello, 1995, Seismic Experimental Evidence for Thin-Skinned Horizontal Shortening by Convergent Radial Gliding on Evaporites, Deep-Water Santos Basin, in Jackson M.P.A., R.G. Roberts, and S. Snelson, eds, Salt Tectonics: a Global Perspective: AAPG Memoir 65, p. 305-321.
Conceição, J.C.J., P.V. Zalán, and S. Wolff, 1988, Mecanismo, Evolução e Cronologia do Rift Sul-Atlântico: Boletim de Geociências da Petrobras, v. 2 , n.4, p. $255-265$.

Demercian, L.S., P. Szatmari, and P. R. Cobbold, 1993, Style and Pattern of Salt Diapirs due to Thin-Skinned Gravitational Gliding, Campos and Santos Basins, Offshore Brazil: Tectonophysics, v. 228, p. 393-433.

Dias, J.L., J.Q. Oliveira, and J.C. Vieira, 1988, Sedimentological and Stratigraphic Analysis of the Lagoa Feia Formation, Rift Phase of Campos Basin, Offshore Brazil: Revista Brasileira de Geociências, v.18, p.252-260.

Dias J.L., J.L. Scarton, F.R. Esteves, M. Carminatti, and L.R. Guardado, 1990, Aspectos da Evolução Tectono-Sedimentar e a Ocorrência de Hidrocarbonetos na Bacia de Campos, in Raja Gabaglia G.P. and E.J. Milani, eds, Origem e Evolução de Bacias Sedimentares, Petrobras, p.333-360.

Dias-Brito, D., 1982, Evolução Paleoecológica da Bacia de Campos durante a Deposição dos Calcilutitos, Margas e Folhelhos da Formação Macaé (Albiano e Cenomaniano?): Boletim Técnico da Petrobras, v.25, p.84-97.

Dias-Brito, D., 1987, A Bacia de Campos no Mesocretaceo-Uma Contribuição a Paleoceanografia do Atlantico Sul Primitivo: Revista Brasileira de Geociências, v.17, p.162-167.

Dias-Brito, D. and R.L.M. Azevedo, 1986, As Sequências Deposicionais Marinhas da Bacia de Campos sob a Ótica Paleoecológica: XXXIV Congresso Brasileiro de Geologia, Goiânia, p.38-49.

Esteves, F.R., A.R. Spadini, and M. Saito, 1987, A Sedimentação Albo-Turoniana (Formação Macaé) da Bacia de Campos:I Simpósio de Geologia do RJ-ES, p.27-42.

Falvey, D.A.,1974, The Development of Continental Margins in Plate Tectonic Theory: The APEA Journal, v.14, n.1, p.95-106

Feijó, F.J., 1994, Bacias de Sergipe e Alagoas: Boletim de Geociências da Petrobrás, Rio de Janeiro, v.8, n.1, p.149-161.

Figueiredo, A.M.F., 1981, Depositional Systems in the Lower Cretaceous Morro do Chaves and Coqueiro Seco Formations and their Relationship to Petroleum Accumulations: Middle Rift Sequence, Sergipe/Alagoas Basin, Ph.D. Thesis, University of Texas of Austin, 302p.

Figueiredo, A.M.F., and W.U. Mohriak, 1984, A Tectônica Salífera e as Acumulações de Petróleo da Bacia de Campos: XXXIII Congresso Brasileiro de Geologia , p.1380-1394.

Figueiredo, A.M.F., J.A.E. Braga, J.C. Zabalaga, J.J. Oliveira, G.A. Aguiar, O.B. Silva, L.F. Mato, L.M.F. Daniel, and L. P. Magnavita, 1994 Recôncavo Basin, Brazil: a Prolific Intracontinental Rift Basin, in Landon, S.M., ed, Interior Rift Basins: AAPG Memoir 59, p.157-203.

Garcia, A.J.V., 1991, Evolução Sedimentar da Sequência Pré-Rift das Bacias Costeiras e Interiores do Nordeste Brasileiro: Pesquisas, Instituto de Geociênicas, UFRGS, v.18, p.3-12.

Guardado, L.R. and A.R. Spadini, 1987, Evolução Deposicional e Distribuição das Fáceis do Macaé Inferior (Eomesoalbiano, Bacia de Campos): Boletim de Geociências da Petrobrás, v.1, p.237-240.

Guardado, L.R., L.A.P. Gamboa and C.F. Luchesi, 1989, Petroleum Geology of the Campos Basin, a Model for a Producing Atlantic-Type Basin, in Edwards J.D. and P.A. Santogrossi, eds, Divergent/Passive Margin Basins: AAPG Memoir 48, p.3-79.

Harry, D. L. and D.S. Sawyer, 1992, A Dynamic Model of Extension in the Baltimore Canyon Trough Region: Tectonics, v.11, n.2, p.420-436.

Henry, S.G. and W. Brumbaugh, 1995, Pre-Salt Rock Development on Brazil's Conjugate Margin: West African Examples: 4th International Congress of the Brazilian Geophysical Society, Rio de Janeiro, Expanded Abstracts, v.I, p.68-70.

Hinz, K., 1981, A Hypothesis on Terrestrial Catastrophes: Wedges of Very Thick Oceanward Dipping Layers beneath Passive Continental Margins: Geologisches Jahrbuch, E-22, p.3-28.

Koutsoukos, E.A.M., 1984, Evolução Paleoecológica do Albiano ao Maestrichtiano na Área Noroeste da Bacia de Campos, Brasil, com base em Foraminíferos: XXXIII Congresso Brasileiro de Geologia, v.2, p.685.

Koutsoukos, E. A. M., 1987, A Área Noroeste da Bacia de Campos, Brasil, do Mesocretáceo ao Neocretáceo: Evolução Paleoambiental e Paleogeográfica pelo Estudo de Foraminìferos: Revista Brasileira de Geociências, v.17, p.168-172.

Koutsoukos, E.A.M. and D. Dias-Brito, 1987, Paleobatimetria da Margem Continental do Brasil durante o Albiano: Revista Brasileira de Geociências, v.17, p.86-91.

Martins, C.C., C.A. da Costa, C.E. Theodoro, L.R. Guardado, and V.F. Andrade, 1995, 3-D Seimic: a Successful Strategy in Campos Basin: The Leading Edge, p.701-704.

Matos, R.M.D., 1992, The Northeastern Brazilian Rift System: Tectonics, v.11, p.766-791.

McKenzie, D., 1978, Some Remarks on the Development of Sedimentary Basins: Earth and Planetary Science Letters, v.40, p. 25-32. 
Mello, M.R., W.U. Mohriak, E.A.M. Koutsoukos, and G. Bacoccoli, 1994, Selected Petroleum Systems in Brazil, in Magoon L.B. and W.G. Dow, eds, The Petroleum System - from Source to Trap: AAPG Memoir 60, p.499-512.

Mizusaki, A.M.P., A. Thomaz Filho, and J.G. Valença, 1988, Volcano-Sedimentary Sequence of Neocomian age in Campos Basin (Brazil): Revista Brasileira de Geociências,v. 18, p. 247-251.

Mohriak, W.U., 1995. Salt tectonics structural styles: contrasts and similarities between the South Atlantic and the Gulf of Mexico. In:Travis, C.J., Harrison, H., Hudec, M.R., Vendeville, B.C., Peel, F.J., and Perkins, B.E. (eds.), Salt, Sediment and Hydrocarbons, GCSSEPM Foundation 16th Annual Research Conference, Houston, Texas, p. 177-191.

Mohriak, W.U., R. Hobbs, and J.F. Dewey, 1990 a, Basin-Forming Processes and the Deep Structure of the Campos Basin, Offshore Brazil: Marine and Petroleum Geology, v.7, p.94-122.

Mohriak, W.U.,A. Z. Barros, and A.Fujita, 1990 b, Magmatismo e Tectonismo Cenozóicos na Região de Cabo Frio, RJ: XXXVII Congresso Brasileiro de Geologia, Natal, v. 6., p.2873-2885.

Mohriak, W.E., M.R. Mello, J.F. Dewey, and J.R. Maxwell, 1990 c, Petroleum Geology of the Campos Basin, Offshore Brazil, in Brooks J., ed., Classic Petroleum Provinces: Geological Society Special Publication 50, p.119-141.

Mohriak, W.U., J.H.L. Rabelo, R.D. Matos, and M.C. Barros, 1995 a, Deep Seismic Reflection Profiling of Sedimentary Basins, Offshore Brazil: Geological Objectives and Preliminary Results in the Sergipe Basin: Journal of Geodynamics, v.20, p.515-539.

Mohriak, W.U., Macedo, J.M., Castellani, R.T., Rangel, H.D., Barros, A.Z.N., Latgé, M.A.L., Ricci, J.A., Misuzaki, A.M.P., Szatmari, P., Demercian, L.S., Rizzo, J.G., and Aires, J.R., 1995 b. Salt tectonics and structural styles in the deep-water province of the Cabo Frio region, Rio de Janeiro, Brazil, in: M.P.A. Jackson, D.G. Roberts, and S. Snelson (eds.), Salt tectonics: a global perspective. AAPG Memoir 65, p. 273-304.

Mohriak, W.U., M. Bassetto, and I.S. Vieira,1998, Crustal Architecture and Tectonic Evolution of the Sergipe/Alagoas and Jacuípe Basins, Offshore Northeastern Brazil: Tectonophysics, v. 288, p. 199-220.

Mutter, J.C., 1985, Seaward Dipping Reflectors and the Continent-Ocean Boundary at Passive Continental Margins: Tectonophysics, v.114, p.117131.

Mutter, J.C., M. Talwani, and P.L. Stoffa, 1982, Origin of Seaward-Dipping Reflectors in Oceanic Crust off the Norwegian Margin by "Subaerial SeaFloor Spreading": Geology, v.10, p. 353-357.

Ojeda, H.A.O., 1982. Structural Framework, Stratigraphy, and Evolution of Brazilian Marginal Basins: AAPG Bulletin, v.66, p.732-749.

Palma, J.J.C., 1984. Fisiografia da área oceânica, in:C. Schobbenhaus, D. A. Campos, G. R. Derze, and H. E. Asmus (eds.), Geologia do Brasil, MME/DPNPM, Brasília, 1984, p. 441.

Pereira, M.J. and F.J. Feijó, 1994, Bacia de Santos: Boletim de Geociências da Petrobras, v. 8, p. 219-234.

Pereira, M.J., C.M. Barbosa, J. Agra, J.B. Gomes, L.G.F. Aranha, M. Saito, M.A. Ramos, M.D. Carvalho, M. Stamato, e O. Bagni, 1986, Estratigrafia da Bacia de Santos: Análise das Sequências, Sistemas Deposicionais e Revisão Lito-Estratigráfica: XXXIV Congresso Brasileiro de Geologia, Goiânia, v.1, p.65-79.

Peres, W.E., 1993, Shelf-Fed Turbidite System Model and its Application to the Oligocene Deposits of the Campos Basin, Brazil: AAPG Bulletin, v.77, p.81-101.

Ponte, F.C. and H.E. Asmus, 1978, Geological Framework of the Brazilian Continental Margin: Geologische Rundschau, v.67, p.201-235.

Ponte, F.C., J.R. Fonseca, and A.V. Carozzi, 1980, Petroleum Habitats in the Mesozoic-Cenozoic of the Continental Margin of Brazil, in Miall D.A., ed., Facts and Principles of World Petroleum Occurrence: Canadian Society of Petroleum Geologists, Memoir 6, p.857-886.

Rabinowitz, P.D. and J. LaBrecque, 1979, The Mesozoic South Atlantic Ocean and Evolution of its Continental Margins: Journal of Geophysical Research, v.84, p.5973-6002.

Rangel, H. D., F. A. L. Martins, F. R. Esteves, and F. J. Feijó, 1994, Bacia de Campos: Boletim de Geociências da Petrobras, v. 8, p. 203-218.

Schlager, W., 1981, The Paradox of Drowned Reefs and Carbonate Platforms: GSA Bulletin, v.92, p.197-211.

Schlager, W., 1989, Drowning Unconformities on Carbonate Platforms, in Crevello P.D., J.L. Wilson, J.F. Sarg, and J.F. Read, eds, Controls on Carbonate Platform and Basin Development: SEPM Special Publication 44, p. $15-25$.

Severino, M.C.G. and Gomes, B.S., 1991. Projeto Leplac: Interpretação preliminar dos dados sísmicos e gravimétricos do Prospecto LEPLAC-I. Segundo Congresso Internacional da Sociedade Brasileira de Geofísica Resumos Expandidos, Salvador, BA. Vol. II, p. 597-602.
Souza Cruz, C.E., 1995, Estratigrafia e Sedimentação de Águas Profundas do Neogeno da Bacia de Campos, Estado do Rio de Janeiro, Brasil, Tese de Doutorado, UFRGS, $186 \mathrm{p}$.

Souza, K.G., R.L. Fontana, J. Mascle, J.M. Macedo, W.U. Mohriak, and K. Hinz, 1993, The Southern Brazilian Margin: an Example of a South Atlantic Volcanic Margin: Third International Congress of the Brazilian Geophysical Society, Rio de Janeiro, v.2, p.1336-1341.

Zalán, P.V.,S. Wolff, M.A.M. Astolfi, I.S.Vieira, J.C.J. Conceição, V.T. Appi, E.V.S. Neto, J.R. Cerqueira, and A. Marques, 1990, The Paraná Basin, Brazil in Leighton, M.W., D.R. Kolata, D.S. Oltz, and J.J. Eidel, eds., Interior Cratonic Basins: AAPG Memoir 51, p. 681-701.

César Cainelli has been with PETROBRAS Company since 1979. Senior explorationist with Ph.D (1992) in the University of Texas at Austin, he has leading several multidisciplinary groups that evaluated the hydrocarbon potential of offshore Brazilian basins. He has been invited professor of Brazilian Geology, Sequence Stratigraphy, and Deep Water Depositional Systems since 1992 in PETROBRAS internal courses, Brazilian universities and abroad. He was AAPG instructor for the Geology of Atlantic Eastern Brazilian Basins Course. His main focus is on basin analysis, deep water regions and turbidite systems. Actually he performs international exploratory evaluation for BRASPETRO, PETROBRAS overseas company.

Webster Mohriak graduated in geology at Universidade de São Paulo (1977) and received his Ph.D in Geology at Oxford University in 1988. Senior explorationist at Petrobras, he has been conducting regional basin analysis projects since 1982, with special emphasis on petroleum geology and tectonic evolution of the South Atlantic passive margin sedimentary basins. He has been teaching several in-house short courses at Petrobras since 1989, as well as in several Brazilian universities as invited and visiting professor, particularly in the area of extensional tectonics, salt tectonics, and basin analysis. His main interests are petroleum geology, salt tectonics, and the deep structures of sedimentary basins.
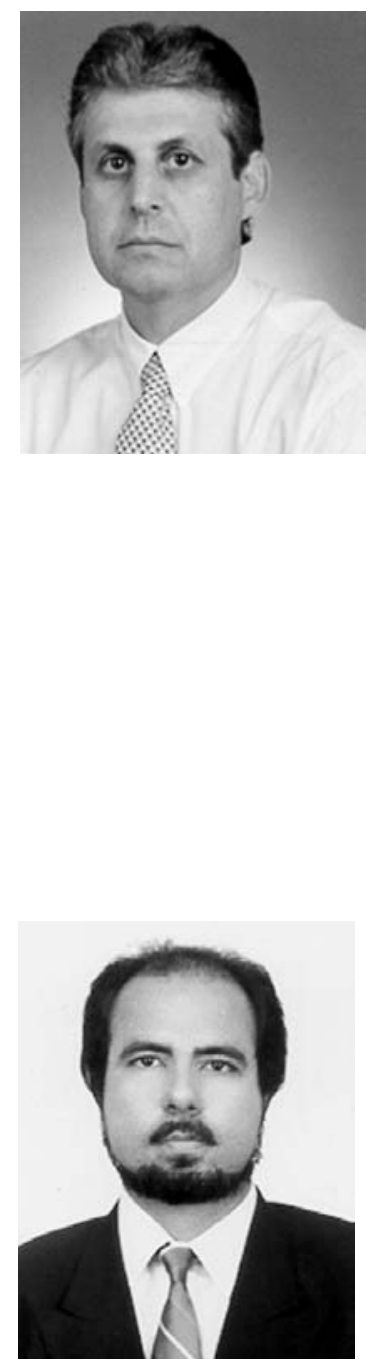